\title{
Statyba
}

\section{ASSESSING UNCONVENTIONAL METHODS OF THERMAL INSULATION}

\section{B. Janińska PhD (Civil Eng.)}

To cite this article: B. Janińska PhD (Civil Eng.) (2000) ASSESSING

UNCONVENTIONAL METHODS OF THERMAL INSULATION, Statyba, 6:3, 213-219, DOI:

$10.1080 / 13921525.2000 .10531589$

To link to this article: https://doi.org/10.1080/13921525.2000.10531589

曲 Published online: 26 Jul 2012.

Submit your article to this journal $\pi$

III Article views: 48 


\section{ASSESSING UNCONVENTIONAL METHODS OF THERMAL INSULATION}

\section{B. Janińska \\ Institute of Structural Engineering}

\section{Introduction}

Commonly used methods of amending thermal insulation efficiency of walls in buildings are principally based on making the partition thicker. Although the location of the insulating element has no influence on the value of thermal resistance, it is because of the risk of frost penetration through the insulated partition, that it is recommended to apply insulating layers from the outside. A brick wall satisfying the current requirements of thermal insulation (overall heat transfer coefficient $U \equiv 0.3 \mathrm{~W} /\left(\mathrm{m}^{2} \cdot \mathrm{K}\right)$ should be almost $2.5 \mathrm{~m}$ thick. Due to the fact that thermal insulation materials are. indeed, used (for example, styrofoam or rockwool), the required value of thermal resistance can be obtained from as little as over 10 centimetres of the heat insulation layer.

In spite of a relative reduction in thickness of the insulation layer, the traditional heat insulation methods may not always be applied. In case of historical buildings, for example, we are obliged to retain the original shape and style of the facade and this, in turn, disqualifies the usage of external layers of insulation.

One of the effects of research into new insulation materials are, for example, thermal insulation paints, applied in thin coats on the internal surfaces of partitions. The manufacturers praise their increased capability to reflect the heat radiation which is supposed to reduce the loss. of heat.

\section{Models of reducing heat losses thanks to internal partitions}

The solution to the problem of reducing heat losses in a building partition is to minimise the stream of heat $Q$. flowing through the external surface of this partition [1]. For the transient process of unidimensional heat influx, described by Fourier's theory, the concept takes the following form:

$$
Q_{z}(\tau)=\int_{\tau_{p}}^{\tau_{k}} q_{z}(\tau) d \tau,
$$

where integration range from the initial instant $\tau_{p}$ to the final instant $\tau_{k}$, embraces the whole heating season, and it is not possible to obtain any reduction in heat losses due to the shortening of the heating season.

The limitation of the escaping heat stream is possible by way of increasing the heat resistance of the partition. which will result in a less dense stream of heat:

$$
q z(\tau)=q(g, \tau)=-\lambda \frac{\partial T(g, \tau)}{\partial x}
$$

where $\lambda$ is the heat transfer coefficient; $x$ is a spatial variable; $x=g$ signifies the external edge, and the temperature over the thickness of the partition is described by the following function: $T=T(x, \tau)$.

A similar effect can be obtained by reducing the density of the heat flux entering the partition. It is possible thanks to a modification of the value of $\alpha_{w},-$ the heat take-over coefficient, which is decisive regarding the manner of heat transfer on the borderline between the partition and the environment:

$$
\begin{gathered}
q_{w}(\tau)=-\lambda \frac{\partial T(0, \tau)}{\partial x}=-\alpha_{w}\left[T_{p w}(\tau)-T_{w}(\tau)\right], \\
\alpha_{w}=\alpha_{w k}+\alpha_{w r}
\end{gathered}
$$

where $\alpha_{w \cdot k}, \alpha_{1 r}$ are heat convection and radiation takeover coefficients, $T_{p w}, T_{w}$ is the temperature of the air and of the surface on the inside of the partition.

It is, therefore, possible to reduce heat losses as a result of increasing the thermal resistance of the construction material layers, or as a result of changing the properties of the surface of a partition.

The graphic interpretation of the change in thermal resistance of the partition, and of the distribution of temperatures regarding the model of a determined heat flow, is shown in Fig 1, where the whole of the added heat transfer 
a)

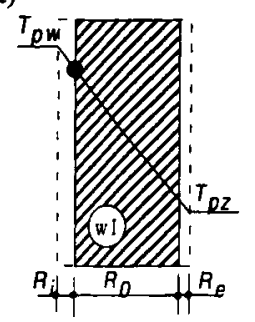

b)

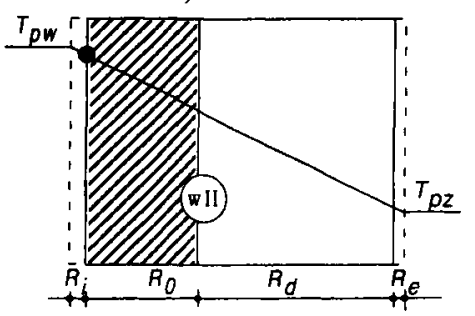

c)

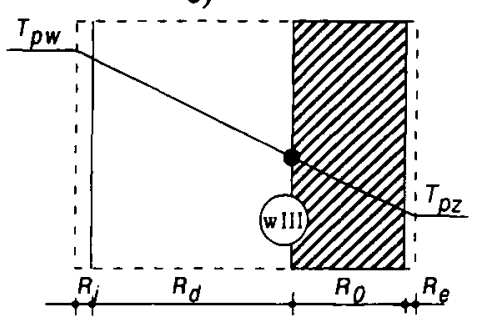

Fig 1. The graph illustrating the modifications in thermal properties of the partition: a - the partition before adding on thermal insulation (wI), b - traditional external insulation (wII), c - untypical "fictitious" heat insulation; change in the influx resistance (wIII)
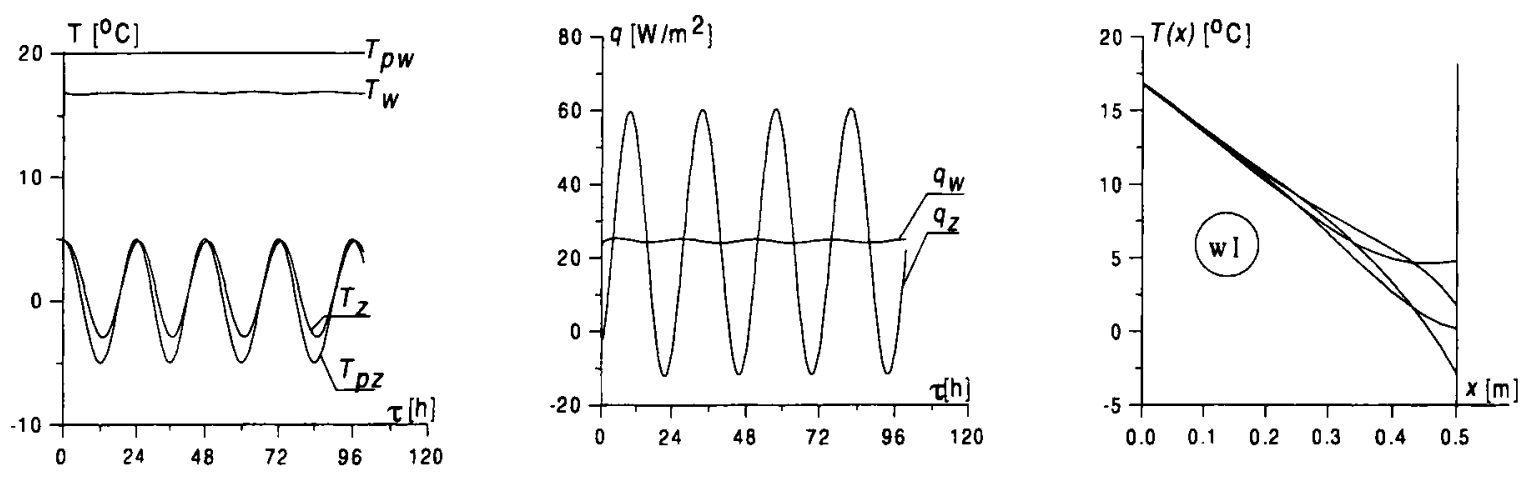

Fig 2. Distribution in initial-boundary functions in the basic process (wI)

presents itself either as the external layer of the insulation material (Fig lb), or as the increase in the influx resistance (Fig 1c).

\section{Simulating quasi-determined processes}

\subsection{Description of the tasks}

Using our own computer software, based on a manifest pattern of finite differences, we carried out simulations of a quasi-determined process of heat flowing through obstacles (six options), for boundary conditions formulated in the following way: $A=24 \mathrm{~h}$, $T_{p w}(\tau)=20^{\circ} \mathrm{C}, \quad T_{p z}(\tau)=T_{0} \cos (\boldsymbol{\omega} \tau), \quad T_{0}= \pm 5^{\circ} \mathrm{C}$, $\bar{\omega}=(2 \pi) / A$.

Option wI is the basic process, generated for the partition $g=0.5 \mathrm{~m}$ thick, $\lambda=0.77 \mathrm{~W} / \mathrm{m} \cdot \mathrm{K}$, and the temperature equalisation factor $a=0.0018 \mathrm{~m}^{2} / \mathrm{h}$. Fig 2 shows the graphs of air and partition surface temperatures, surface densities of heat flux, and inner temperature distributions for $\tau=78,84,90,96 \mathrm{~h}$ obtained after breaking off the initial condition $(T(x, 0)=T(x, \tau)$ for $\tau=96 \mathrm{~h})$.

The boundary conditions obtained in the basic process were then used, either modifying or remaining them unchanged, to solve the task of analysing the subsequent options (wII $\div$ wVII). The abbreviated notation of the processes and results has been presented in Table 1.

Basing on tasks wII and wIII, we can draw a comparison between processes involving partitions characterised by the same thermal resistance and boundary conditions which, nevertheless, had been thermally insulated in a different way.

Option wII is a traditional thermal insulation applied on the outside of a partition (the following factors assumed for this insulation: $g=0.075 \mathrm{~m}, \lambda=0.0457 \mathrm{~W} / \mathrm{m} \cdot \mathrm{K}$, $\left.\mathrm{a}=0.004 \mathrm{~m}^{2} / \mathrm{h}, R_{d}=1.64\left(\mathrm{~m}^{2} \cdot \mathrm{K}\right) / \mathrm{W}\right)$.

Option wIII: this is an unconventional thermal insulation (the "fictitious" one); and it is based on increasing the resistance to the influx $R, \mathrm{o}$ by a value equivalent to the traditional thermal insulation (the $R_{d}$ from the wII option).

Options wIV $\div w V I$ present the influence of the change of internal boundary conditions on the values of density $q_{z}$ of heat flux, and wVII is a solution involving and merging the results of the modification of properties of the partition surface with the added thermal resistance of a traditional thermal insulation. 


\subsection{The results of simulation}

Temperature distribution inside the partition has been shown in Fig 3, and the comparison of the function of density of the streams of heat $q_{z}(\tau)$ has been shown in Fig 4.

The simulations which have been carried out have proved that, regarding options wII and wIII, a reduction of heat flux $Q_{z}$ can be obtained at the level of $\sim 30 \%$. regarding options wIV $\div$ wVI at the level of $\sim 90 \%$, and regarding options $w$ VII at the level of $-50 \%$ of the value of the original heat flux (wI), see Table 1.

Table 1. Seven numerically simulated processes

\begin{tabular}{|c|c|c|c|c|c|}
\hline & \multirow[t]{2}{*}{ Type of partition } & \multirow{2}{*}{$\begin{array}{l}\text { Boundary } \\
\text { conditions }\end{array}$} & \multicolumn{2}{|c|}{$\begin{array}{l}\text { Mean value } \\
\tau=72.5 \div 96 \mathrm{~h}\end{array}$} & \multirow{2}{*}{$\begin{array}{c}\frac{q}{q=11} \\
1-1\end{array}$} \\
\hline & & & $\begin{array}{l}T_{w} \\
{ }^{\circ} \mathrm{C}\end{array}$ & $\begin{array}{c}q= \\
\mathrm{W} / \mathrm{m}^{2}\end{array}$ & \\
\hline wl & $\begin{array}{l}\text { No thermal in- } \\
\text { sulation }\end{array}$ & $3-3$ & 16.82 & 24.38 & 1.00 \\
\hline wII & $\begin{array}{l}\text { With traditional } \\
\text { thermal insula- } \\
\text { tion }^{*} \text { ) }\end{array}$ & $3-3$ & 18.92 & 8.08 & 0.33 \\
\hline wIII & $\begin{array}{l}\text { „Fictitious" } \\
\text { thermal insula- } \\
\text { tion }{ }^{*}\end{array}$ & $3-3$ & 5.81 & 8.68 & 0.36 \\
\hline wIV & $\begin{array}{l}\text { No thermal in- } \\
\text { sulation }^{* * 1}\end{array}$ & $2-3$ & 15.44 & 22.62 & 0.92 \\
\hline$w V$ & $\begin{array}{l}\text { No thermal in- } \\
\text { sulation }\end{array}$ & $\begin{array}{c}3-3 \\
T_{p \mathrm{n}}=18^{\circ} \mathrm{C}\end{array}$ & 15.14 & 21.97 & 0.90 \\
\hline$w V I$ & $\begin{array}{l}\text { Unconventional } \\
\text { insulation }\end{array}$ & $3-3$ & 15.15 & 21.98 & 0.90 \\
\hline wVII & $\begin{array}{l}\text { Combined insu- } \\
\text { lation }\end{array}$ & $3-3$ & 18.42 & 12.79 & 0.52 \\
\hline
\end{tabular}

*) - thermal resistance of the insulation $R_{d}=1.64\left(\mathrm{~m}^{2} \cdot \mathrm{K}\right) / \mathrm{W}$ has been assumed as for a material constant thermal insulation paint. such as the Thermo-Shield paint: $\lambda=0.000152 \mathrm{~W} / \mathrm{m} \cdot \mathrm{K}, \mathrm{g}=0.00025 \mathrm{~m} \mid 2]$

${ }^{* *}-q_{n+1 V,}(\tau)=0.9 \cdot q_{n+11}(\tau)$, the reduction in value of density of the boundary flux has been assumed on the basis of reference materials on the Ispo ThermoColor paint |3|.

${ }^{* * *}$ - the increase in thermal resistance pf the partition by $10 \%$, gained thanks to the increase of the resistance to the influx up to the value of $R_{i(\mathrm{VII})}=0.22\left(\mathrm{~m}^{2} \cdot \mathrm{K}\right) / \mathrm{W}$

${ }^{* * * *}$ - the thermal insulation on the inside is a combination of wVI $\left(R_{i}=0.22\left(\mathrm{~m}^{2} \cdot \mathrm{K}\right) / \mathrm{W}\right)$, and the insulation with a thermal insulation layer (like in wII), but with $g=0.07 \mathrm{~m}$, $\left.R_{d(\mathrm{VII})}=1.55\left(\mathrm{~m}^{2} \cdot \mathrm{K}\right) / \mathrm{W}\right)$.

Despite of the outside air temperature oscillation, the temperature of the partition internal surface, regarding all options, was very stable, Fig 3.
In the case of a traditional method of heat insulation, we note an increase of internal surface temperature, as compared with the partition without insulation.

The wIII insulation (the unconventional, "fictitious" one) results in a drastic cooling down of the wall surface, in spite of the fact that the added thermal resistance $R_{d}$ is equal to that of the traditional thermal insulation. Such temperature lowering is very dangerous because of the risk of vapour condensation on the internal surface of the partition, and the risk of fungal infections. Options wV and wVI pose less danger than wIII, nevertheless they do not provide the benefit of equal reduction of heat losses.

The best way of simultaneously reducing the heat losses and protecting against an unfavourable drop in the surface temperature is joining together the modifications in the surface properties (increasing the influx reduction), and adding a bigger thermal resistance of a thin layer of thermal insulation.

According to the marketing information in the pamphlets [2, 3], it is the thermal insulation paints that are supposed to have such properties. Option wVII may be an example hinting at such a solution (due to the numerical considerations, and the lack of percentage definition of share of influx resistance and thermal resistance in the reference materials $[2,3]$, in the total resistance of thermal insulation, the wVII process simulation assumes a thermal insulation with $\mathrm{g}=0.07 \mathrm{~m}$ thick styrofoam, $R_{d}$ $(\mathrm{VII})=1.55\left(\mathrm{~m}^{2} \cdot \mathrm{K}\right) / \mathrm{W}$, and the change in the influx resistance to the value of $\left.R_{i}=0.22\left(\mathrm{~m}^{2} \cdot \mathrm{K}\right) / \mathrm{W}\right)$.

According to $[2,3]$, due to the fact that the paint with an increased light reflection coefficient has been used. part of thermal energy does not enter the partition, or returns into the protected room. The achieved subjective change in temperature of radiation of partition surfaces makes it possible to reduce the air temperature indoors by $\sim 2^{\circ} \mathrm{C}$, and saves approximately $10 \%$ in energy expenditure (estimated according to the energy balance in the researched buildings).

Regarding the $w V$ option, the real reduction to $\sim 90 \%$ in the heat flux has been achieved. but it was only the result of lowering the air temperature indoors which, in turn, resulted in reducing the density of the heat influx through the partition internal surface. down to the level assumed for option IV, i.e., $q_{\mathrm{w}^{\prime}(\mathrm{IV})}(\tau)=0.9 \cdot q_{\mathrm{N}}(\mathrm{II})(\tau)$. 
a)

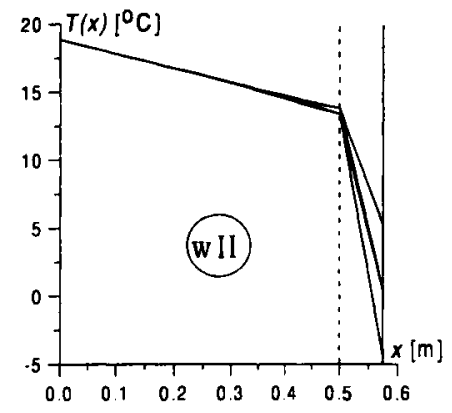

b)

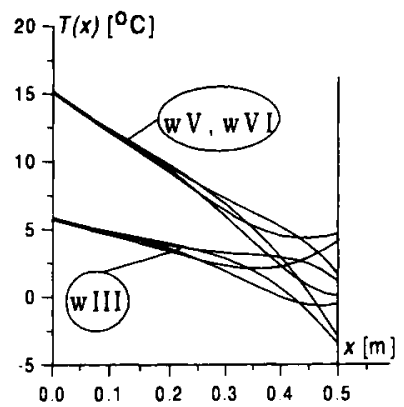

c)

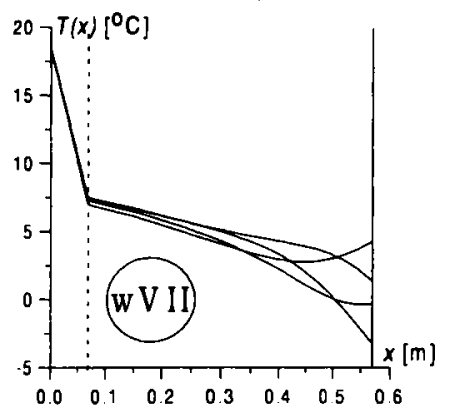

Fig 3. Temperature distribution: $T(x, \tau), \tau=78,84,90,96 \mathrm{~h}$ : a - traditional external insulation (wII), $\mathrm{b}$ - unconventional solutions, $\mathrm{c}$ - internal thermal insulations - combined ( $w \mathrm{VII}$ )

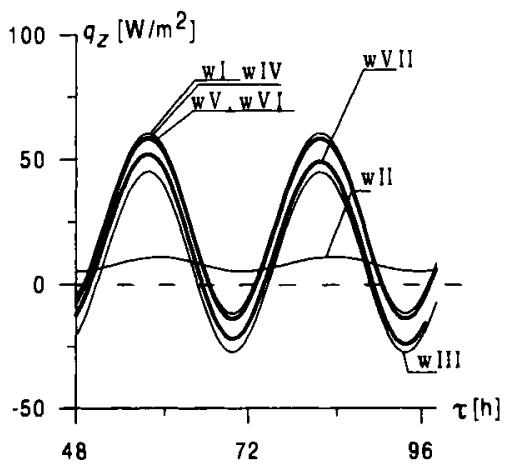

Fig 4. Values of $q_{z}(\tau)$ function for $w \mathrm{l} \div \mathrm{wVII}$

Similar reductions in heat losses have been achieved by means of increasing the influx resistance in the VI option (not taking into consideration the thermal resistance $R_{d}$ of the added thermal insulation paint).

\section{Field research}

\subsection{Research description}

In winter 1998/99, the field research was carried out, aimed at comparing the real effects of using thermal insulation paints with those envisaged by computer simulations.

The research and tests, carried out and divided into some stages, were essentially comparative, ie, pertinent to adjacent fragments of external partitions in the same weather conditions. The comparison of test results achieved in the light of initial-boundary conditions thus formulated, enabled the researchers to reduce the time of testing, and to ignore the influence of the unknown history of the process (see $[1,4]$ ).
The measurement (of the wall surface temperature, the air temperature indoors, and the surface density of the heat influx) was pertinent to walls covered with a coat of paint in question, and with a coat of traditional emulsio 216 paint (the latter shall be called unpainted surfaces).

In the research, we used the TE-2 electronic thermometer, equipped with sensors measuring the temperature on the wall surface and the air temperature, with the reading precision of $\pm 0.1^{\circ} \mathrm{C}$, and the $\mathrm{C}-21$ heat flux density gauge, equipped with sensors with the reading precision of $\pm 0.5 \mathrm{~W} / \mathrm{m}^{2}$.

The first measurement reading was taken approximately 15 minutes after the sensors were put in place, and the following readings after minimum 5 minutes. Every measurement consisted of two readings, and their mean value was calculated.

At the time, during which the field work was done, the air temperature outside varied around approximately $T_{p=}=0 \pm 5^{\circ} \mathrm{C}$.

\subsection{Tests carried out in the office building}

In the office building, the measurements were taken in one of the offices (pok. 25) painted with a thermal insulation paint, and in another office (pok. 26) painted with the traditional emulsion paint.

The tests were essentially momentary measurements in character, and the readings of the measured values were repeated a number of times, in order to arrive at stable value (see Fig 5).

The result was quite surprising, indicating that a much denser flux of heal penetrated through the inner surface of the wall painted with the thermal insulation paint than through that coated with traditional paint. 

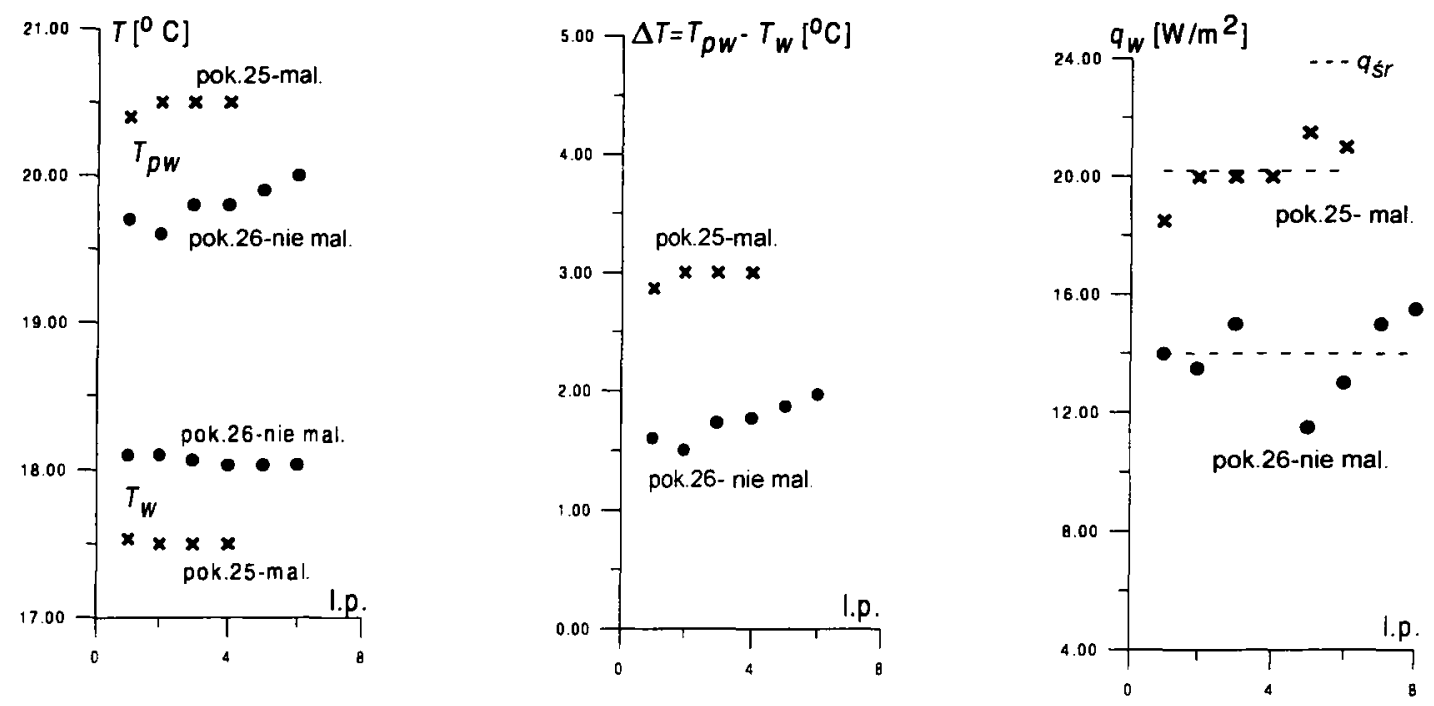

Fig 5. Test results of measurements taken in the office building

The air and wall surface temperature distribution in both rooms indicated, though, that such a flux density assessment was an effect of interpretation of the indirect measurement used in the accessory wall method - the traditional measurement method.

The value of flux density stems from the nominated difference between the wall and air temperatures ( $\Delta T=T_{p w}-T_{w}$ ) which, in this case, is bigger in the room coated with the tested paint. The fact is that the flux density may be different, the more so that the indoor air temperatures were different, and this may be both a result of the way those rooms were painted (the users subjective assessment of the microclimate which enables them to lower the indoor temperature), and may be the reason for differences in wall surface temperature.

No clear lowering the surface temperature of the inside wall was noted.

\subsection{Tests carried out in a block of flats}

In a flat, where only a wall fragment was coated with thermal insulation paint, the measurements were taken over a long time, of more than 20 hours. The measuring sensors were mounted in reflecting locations (primary and secondary), which enabled the reduction of the influence of differences in measurement errors of the sensors themselves. The tests were carried out at the distance of 22 centimetres from the paint coat.
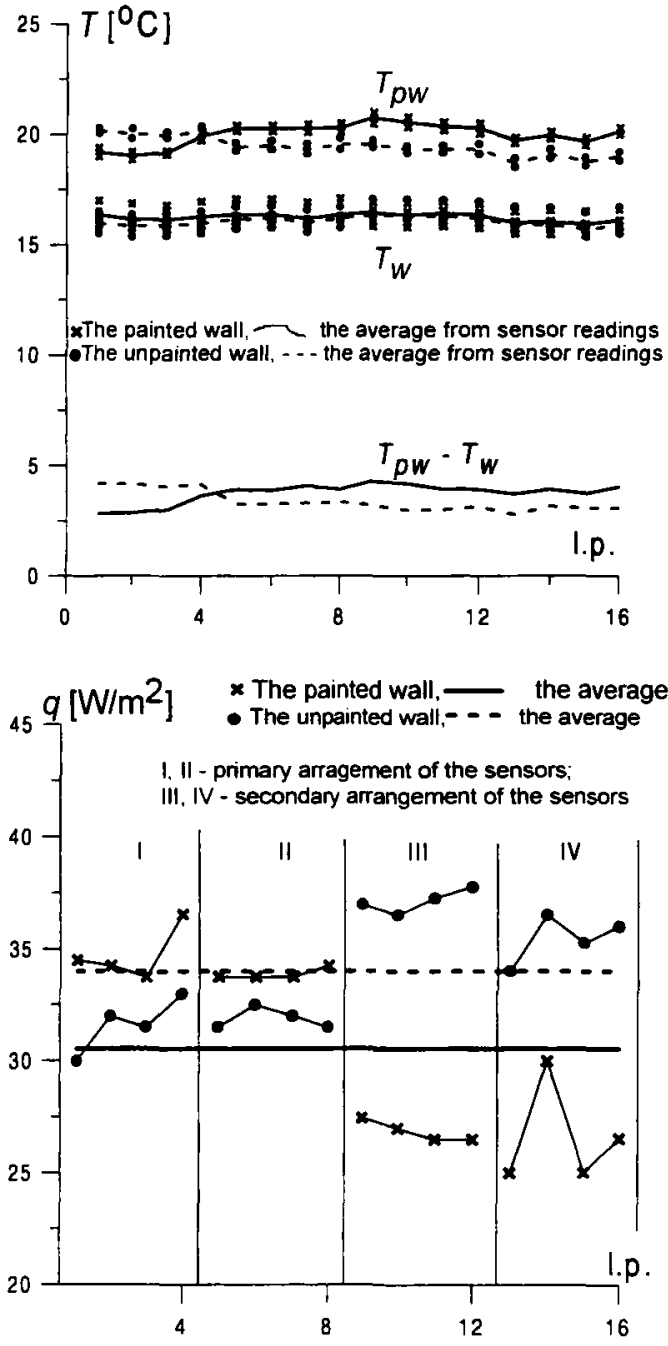

Fig 6. Results of measurements taken in a flat 
Table 2. Measurement results in a block of flats

\begin{tabular}{|l|c|c|c|c|c|c|}
\hline \multirow{2}{*}{} & \multicolumn{3}{|c|}{ The painted wall } & \multicolumn{3}{c|}{ The unpainted wall } \\
\cline { 2 - 8 } & $T_{w}\left|{ }^{\circ} \mathrm{C}\right|$ & $T_{p w}\left|{ }^{\circ} \mathrm{C}\right|$ & $q_{w}\left|\mathrm{~W} / \mathrm{m}^{2}\right|$ & $T_{w}\left|{ }^{\circ} \mathrm{C}\right|$ & $\left.T_{p w} \mid{ }^{\circ} \mathrm{C}\right]$ & $q_{w}\left|\mathrm{~W} / \mathrm{m}^{2}\right|$ \\
\hline The mean value & 16.241 & 19.995 & 30.53 & 16.049 & 19.450 & 34.02 \\
The standard variationstandard & 0.44 & 0.53 & 4.01 & 0.46 & 0.48 & 2.55 \\
The minimum value & 15.40 & 18.85 & 25.00 & 15.35 & 18.5 & 30.00 \\
The max. Value & 17.10 & 21.00 & 36.5 & 17.05 & 20.35 & 37.75 \\
\cline { 2 - 8 } & & & & & & \\
\hline
\end{tabular}

The selected results were shown in Table 2, and in Fig 6 (under the function of a number of measurements taken).

The measurements taken in the flat did not confirm the results of tests on heat flux densities, carried out in the office block. The mean values of heat flux density for both walls were quite close, Table 2.

Just like in the office block, regarding the painted wall. the bigger difference in temperature between the air and the partition surface was noted, than in the case of the unpainted wall. No reduction in the wall temperature was found, which might be dangerous from the point of view of possible vapour condensation (see wIII).

\subsection{Summary of the field research}

The field research does not indicate clear differences between the properties of the compared wall surfaces.

Temperature differences, as well as differences in heat flux densities for the areas coated with the tested paint, and with traditional paint, were small (approximately $\sim 0.5^{\circ} \mathrm{C}$ as far as the temperature is concerned. and approximately $\sim 5 \mathrm{~W} / \mathrm{m}^{2}$ for heat flux densities). Therefore, on the basis of the research, it is neither possible to confirm, nor to question the information contained in the manufacturer's pamphlet regarding the properties of the thermal insulation paint.

No dangerous cooling down of the wall has been noted, and such a cooling ought to have occurred with the significant increase of the heat influx resistance values. The application of the tested thermal insulation paint does not, therefore. result in a significant reduction of the temperature which might bring about the risk of vapour condensation on the surface.

It has been stated that the traditional measurement instruments are not suited to test new, unconventional and untypical building materials (for example. thermal insulation paints).
In order to avoid ambiguity in the assessment of the research results, the following issues should be additionally defined, apart from those which stem from the fact that the measurements were being taken in unstable conditions:

- the influence of new properties of the material on the interpretation of the result of indirect measurements (the measurement of the heat flux density, the thermovisual measurement of surface temperature),

- the problem of minimum and maximum duration of measurement (the definition of minimum duration results from the necessity of stabilising the conditions and, simultaneously, fixing the sensors in one position over a long period of time makes void in the specific properties of the surface),

- the influence of the painted walls number on the efficiency of the modification of surface properties (in the flat, only a small fragment of the wall was actually painted, and in the office block, the whole area of the surrounding partitions).

\section{Conclusions and summary}

Limiting the heat flux through partitions is traditionally achieved by way of adding an external layer of thermal insulation. Nonetheless it is also possible to use the solution based on modifying the internal surface properties of the partition.

Such a solution requires the usage of new materials, whose practical properties still need a thorough analysis. because they have not had a chance of being verified by years of usage.

The assessment of properties of such materials in natural conditions poses additional problems, apart from those which result from unstable conditions during the actual field work. 
Using standard methods and standard control and measurement instruments to assess new materials may be insufficient, and particularly in the case of indirect measurements.

Such a situation requires defining the methods of assessment of the properties of new, unconventional materials. and calls for the limited trust in marketing information contained in pamphlets promoting an unknown product.

\section{References}

1. A. Gawęcki. B. Janińska. Wyznaczanie wspólczynnika przenikania ciepla przegród budowlanych // COW. Determining heat transfer coefficient in building partitions, 24, 5 . 1992. s. 109-114.

2. B. Metschkow, J. Peters, St. Maziarka. Thermo-Shield Material termoizolacyjny, ekologiczny i higieniczny do "zdrowych domów" // Konferencja "Zdrowy Dom - Dom promujacy Zdrowie". Thermo-Shield: a thermal insulation material suitable for "healthy homes": ecological and clean. Warszawa. 1998

3. The net page address: http://www.ispo-online.de/

4. A. Gawęcki. B. Janińska. Problemy analizy i identyfikacji w procesach nieustalonego przeplywu ciepla // Zeszyty Naukowe PP, Problems of the analysis and identification in the processes of unstable heat transfer, 39/1995, s. 103-131.

\section{NETRADICINIU ŠILUMOS IZOLIAVIMO METODU VERTINIMAS}

\section{B. Janińska}

\section{Santrauka}

Šilumos srautui. einančiam per pertvaras. sulaikyti paprastai naudojamas šiluminès izoliacijos sluoksnis. Tačiau tokius pačius rezultatus galima gauti ir keičiant pertvarų vidinio paviršiaus ypatybes. Tokiam sprendimui igyvendinti reikia nauju medžiagų. Tačiau ju savybes reikia atidžiai ištirti. nes jos nebuvo patikrintos ilgametes praktikos. Ty medžiagų. naudojamų natüraliomis salygomis. vertinimas kelia papildomų problemų. Standartiniy metodu ir standartinès kontrolès bei iprastinès matavimų analizés gali nepakakti naujosioms medžiagoms ivertinti. spač jei bus taikomi netiesioginiai matavimai. Tam reikia metodų. kuriais bus tiriamos naụjų. netradicinių medžiagụ sàvybes: be to. reiktu atsargiai vertinti prekybininkụ brošiūrose teikiamą informaciją apie nežinomus gaminius.

Barbara JANIŃSKA. PhD (Civil Eng.). Assistant Professor at the Chair of Construction Engineering, Institute of Structural Engineering: Civil Engineering, Architecture, and Environmental Engineering Department of the Poznan University of Technology. Ul. Piotrowo 5. 60-965 Poznań. Poland. E-mail: barbara.janinska@put.poznan.pl

Research interests: construction physics, mycology, durability and strength of constructions, and protection against corrosion.

Iteikta 19991215 